\title{
MINIMIZING THE IMPACT OF MINING ACTIVITIES FOR SUSTAINABLE MINED-OUT AREA CONSERVATION IN NIGERIA
}

\author{
Nwadialor, I. J. \\ Department of Surveying and Geoinformatics, \\ Federal University of Technology, Minna, Nigeria
}

\begin{abstract}
Nigeria is endowed with abundant mineral resources. However, their extraction and processing through mining activities especially, of the solid minerals are going on at different scales of intensity. Some of these operations, and their negative impacts to the environment which include: land degradation, ecological disruption giving rise to air, land and water pollution and death of flora and fauna, etc often go on unchecked. These disturbing situations and means to minimize them have surprisingly not been taken seriously because of lack of regulatory implementation impetus or due to the little revenue accruing from these resources which is not even meaningful to be reflected in the nation's Gross Domestic Product (GDP). It is in this regard, that the paper critically reviewed the state of mineral exploitation in Nigeria, its adverse effects on the environment and associated health hazards, including the strategies for hazard reduction, and conservation of mined-out areas. From this review study, it was feared that natural catastrophes such as earthquake and volcanic eruptions - occasioned by possible geomorphological and geostatic equilibrium destabilization may be imminent in the country as a result of these mining activities. It was therefore recommended that a holistic approach to evaluating hazards represented by different kinds of mine waste be put in place by adopting remote sensing and Geographical Information System (GIS) in assessing environmental impact of mining and its new developments.
\end{abstract}

Keywords: Solid mineral, Impact assessment, Mined-out area utilization, Economic resources, Database creation and Environmental sustainability.

\section{Introduction}

Mineral resources are important natural assets of a nation, and palaeontological evidence and information have shown that since man's very beginning, minerals have been taken from the earth and used to make more of life. This may imply that since ages, man has been modifying parts of his environment in the attempt to make himself more comfortable. In some instances, man's activities have caused pollution of his environment up to undesirably high level (Ugodulunwa and Taiwo, 1997). Most of the items used by man are manufactured in industries. However, the extraction of mineral concentrations from the earth, and their processing and use in industries have positive or negative impact on the environment.

Nigeria is endowed with many mineral resources. Some of them include iron ore at (Itakpe), cassiterite (Jos), columbite (Barkin Ladi), lead and zinc (Abakaliki), Kaolin (Nahuta), limestone (Ashaka), Marble (Toto), diatomite (Bularaba), gold (Ilesha), gemstones (Keffi), talc (Kagara), bitumen (east of ljehu Ode), coal (Enugu), petroleum and natural gas (Niger Delta) (op.cit). On earlier related observation Adekoya (1995) stated that Nigeria is endowed with abundant mineral resources (Table 1), which have contributed immensely to the national wealth with associated socio-economic benefits. However, before the minerals can make such impact on the national economy, they must first of all be explored, wrested from the earth, processed and used to manufacture goods. In the process of passing through these stages of mineral exploitation certain damage is done to the environment. Adiuku-Brown (1997a) on the other hand, admitted the earth is said to have originated about 4.5 million years ago. The development of life on the earth she stated was very slow at the beginning and restricted to the aquatic environment. Man appeared on the earth during the Cenozoic era, in the phanerozoic eon. Man needs the mineral resources in the earth for the sustenance of life, technological development and modernization. To meet these needs, man has been steadily tearing up the 
land. Technological advancement has also provided man with the machinery to do a greater devastation to the crust of the earth. The devastative activities of man on the earth include mining, engineering constructions, oil drilling, agriculture, etc. The overall effect is a destabilization of the natural equilibrium of the environment $\sim$ which in most cases end up in environment pollution. Adiuku-Brown (1997b) has the view that the survival needs motivate man to tear up the land in search of food and natural resources. Man is afraid that in future, the resources may be exhausted. Humanistic psychology views needs as deficiencies or anything people perceive as necessary for their overall well-being (Kolesnik, 1978), while Mogbo (1999) observes that in the North East Region of Nigeria, there is a considerable volume of mining work progressing on illegal basis, e.g. the mining of uranium as well as of some harmful radiation and the prevalence of vast derelict land in the village neighbourhood.

On the economic aspects, Adekoya (1995) relatively more recently, starting from 1958, oil and gas in Nigeria have been playing an increasing role in the socio-economic development and growth of the country and have, in fact, overshadowed other economic minerals by contributing over $90 \%$ of the national revenue. On the foreign scene, in reality, Mortimer (1998), the output value of minerals in the United Kingdom does not reflect their ultimate value to the national economy. Minerals are the basic raw materials for the manufacturing, power supply and construction industries. When the values of these sectors, which are almost entirely mineral based, he pointed out, are also taken into account, the figures show that minerals provide the essential raw materials to industrial sectors that contributed about \pm 100 billion or 16 per cent of the total United Kingdom Gross Domestic Product (GDP) in 1996. Equally importantly, more than 70,000 people work directly in the British minerals industry with many thousands more relying indirectly on the industry for their livelihoods.

In another development, Sharma and Joshi (1985) revealed that mining and underground tunnel laying out are difficult due to unfavourable working conditions such as poor lighting or visibility, wet surroundings, smoky environment, etc. The operations require heavy expenditure, and loss of life of men, and materials sometimes may occur due to mine collapse or gas explosion. Other authors have also made contributions in this regard; including: Ajakaiye et al (1989); Adiuku-Brown and Ogazi (1991); Ajayi and Adelaye (1977); Bafor (1979); G.S.N (1987).

It was discovered that many efforts have been expended by researchers in highlighting the hazards of mining to the environment, with little or no attempt on the conservation/restoration strategies to minimize the effects for better human existence and pleasure. The paper, therefore, filled this gap by discussing some hazards, and devising approaches to alternative uses of mined-out area resources through some conservation techniques for the sustainability of the environment. The mining activities as used here in the text encompass: mining operations, exploration and mineral processing.

\section{Mineral Exploitation in Nigeria}

Table 1 (in the appendix) shows the economic mineral potential of Nigeria. Some of the minerals, notably, cassiterite (tin ore), columbite, tantalite, wolframite, lead, zinc, gold and coal have been mined and processed on a commercial scale since the early part of the last century and have made significant contributions to the national revenue and socio-economic development of Nigeria. Other minerals like monazite, xenotime, zirconium, thorite and molybdenite have also been produced in lesser quantities and exported.

At present the minerals listed in Table 2 (see appendix) are currently being exploited (Adekoya, 1995). They are at different levels and scales of exploitation. To a large measure, the scale of operations involved in exploring, mining and processing a mineral determines the intensity and extent of environmental damage.

Environmental impact of mining and mineral processing are in too forms (Ugodulunwa and Taiwo, 1997). One involves scaring of the earth (by digging up part of it) and subsequent effects of this like: erosion, gullying, rock falls, landslide, heaps of waste, siltation of ponds and aquatic ecosystems, subsidence, etc. The other form of impact is pollution of the immediate environment of the marine or the mineral-processing centre. Warren (1973) has observed that 
ill-considered or badly constructed mining and mineral processing system may litter the landscape with unsightly structures, solid waste heaps and transport facilities, pollute air, water and soil and kill vegetation. Thus, in general, a greater damage by these impacts is witnessed in the localities where large-scale exploitation occurs as against areas where small-scale manual winning of minerals is done by tribute workers. For example, large-scale mining of tin and associated minerals on the Jos Plateau is accompanied by a high degree of landscape degradation and some of the environmental problem cited above. Other localities affected by large-scale adverse environmental effects are Niger Delta as a result of oil and gas exploitation; Sagamu, Eekoro, Ashaka and Gboko due to mining of lime-stone and cement manufacture; and Enugu as a result of coal mining. On the other hand, the environmental damage caused by small-scale quarrying of laterite, clay, gravel, stone and gold in various parts of the country by local people, and private entrepreneurs is far less but more difficult to detect and control due to the isolated and nucleated spatial distributions of the effects.

\section{Adverse Effects of Mining and Processing on the Environment}

Before minerals can become useful commodities, they have to undergo the following sequential stages of development: exploration with or without prior processing, mine development, mining and processing. The different stages of mineral development produce adverse effects on the environment.

The first step towards the establishment of a mine is the provision of basic infrastructure like access roads, power and water supply. Thereafter, mining starts by making an opening(s) in the ground. This will affect the physical landscape as it may disturb the water table, alter stream flow, and generate huge amount of dust and noise. If in the open-cast mining, the material of interest is hard rock (e.g granite used for road and building construction), it is extracted by blasting, followed by crushing to obtain the required sizes. Vibrations caused by the blasting can damage structures like buildings, roads, bridges, etc in the vicinity of the quarry. The associated noise can cause ear and heart problems, especially if combined with pulsation as is the case with drilling equipment.

On the other hand, underground mining has minimal effect on the physical landscape. The main effect on the landscape results from subsidence caused by the sub-surface voids created by the mining and removal of materials. Subsidence is usually accompanied by differential horizontal strains, which may adversely affect structures like high rise buildings, dams, roads and bridges.

Mining, in spite of its numerous advantages, unfortunately, has been one of the major causes of environmental degradation in Nigeria. Mining, in addition to the negative effects cited above, produces severa 1 adverse impacts on the environment and these include; a desolate landscape of earth mounds as is the situation in some parts of Plateau State, destroying the scenic beauty in places like Rayfield; agricultural land is rendered barren by mining, with the possibility of causing rural/urban drift; water from mine ponds is used for domestic and industrial purposes. The water in some mine ponds especially in lead-zinc mines is contaminated with toxic trace elements (Adiuku-Brown and Ogazi, 1991); pollution from oil spillage is the primary environmental hazard in oil producing states in Nigeria; etc.

The mining effects from their nature also give rise to air, land and water pollution, thereby constituting health hazards to both terrestrial and aquatic habitats with serious consequences. This will be highlighted because it is critical to the sustainability of live on earth.

\section{Health Hazards Associated With Mining Activities}

The mining, smelting and treatment of ores, for example, such as sulphide ores and the combustion of fossil fuels, emit such gases as carbon dioxide and sulphur dioxide. Quarrying pollutes the air with dust and noise. The processing of uranium zirconium, tantalite, wolframite and tin ores can pollute the air with ionizing radiation. Silica particles pollute the air in proximity to rock drilling sites, in mines and quarries. Asbestos particles pollute asbestos mine 
and processing areas.

Liquid waste from mining/mineral processing requires specialized storage. Most mineral processors dodge this responsibility by running the waste into the nearest stream. This causes serious pollution and destroys aquatic life. Human beings have often got the effect through the food chain or directly through contaminated water. Slime and quartz that were released by kaolin processing plants account for the white coloration of extensive areas near those plants. The slime has affected aquatic life; and the slime and quartz have rendered the farmlands in these areas infertile. This has occasionally generated serious friction between farmers and mineral industrialists. Adekoya (1995) has observed that another effect of the damage, which may not be immediately seen, is the disturbance of the ecological system with possible adverse consequences on the floral and faunal community. He went on to inform that recent environmental impact studies of limestone mining and cement industry in Sagamu area reveal a declining Kolanut output from the plantations within a few kilometres radius of the cement factory. This phenomenon is most probably associated with dust pollution as plenty of dust is discharged into the air mainly from the cement factory. The particulate matter eventually gets deposited on the kolanut leaves and flowers as well as the soil supporting the plants. The overall effect of this is that the photosynthetic and fruiting ability of the kolanut trees is impaired with consequent decrease in kolanut production. Honda (1991), in his study of monitoring of revegetation area in Asio (Tokyo in Japan) devastated land, caused by copper mines pollution, using aerial photography and satellite remote sensing, observed that sulphurous acid gas exerted a serious influence on trees within $149 \mathrm{~km}^{2}$ around the Bessemer smelting plant located in the mine area. Within another $38 \mathrm{~km}^{2}$, he said; only plants, which were resistant to sulphurous acid gas such as bamboo trees remained. Frequent floods and sediment disasters, which seemed to be caused by destruction of forest, as a result, had a serious unpleasant influence on the crops, and health of villagers in ruins. Over the 33 years, from 1956 to 1988, he revealed, 1168 hectares of hill-side seeding and 339 of check-dams have been undertaken, as restoration attempt at the cost of 119billion Yen. Through these measures, the area has considerably recovered; but even at present a large devastated area is left as it stands, where any work is hard to be done. So, for the overall restoration of vegetation, a large amount of cost, long term, and difficult measures are expected, he concluded.

Mining activities generate socio-environmental problems such as the formation of "ghost towns" which are abandoned towns and previous bubbling mining communities. Two causes of ghost towns are illustrated in Nigeria. The migration of mining communities from a locality as a result of mineral depletion is a major cause of some ghost towns. For example, Sofon Birnin Gwari was a town that once thrived on gold mining between 1914 and 1938 but was abandoned due to the exodus of miners and prospectors to the Plateau tinfields in the early 1940s. A few villages on the Jos Plateau have been abandoned because of death of many people under mysterious circumstances. The mysterious deaths have been traced to a high level of radiations released by monazite-rich sand used for building the houses the deceased lived in. Another obvious effect of radiation was noticed when a cat living in the house of its dead owners produced a kitten with only one leg due to genetic mutation typical of radiation absorption (Adekoya, 1995).

In another development, inhalation of dust produced in mines causes black lung disease (Pneumoconiosis) which is incurable. Silicosis, a lung fibrosis is caused by the accumulation of silica particles. Asbestosis is caused by the inhalation of asbestos. Ionizing radiation from geologic and mining activities cause lung cancer. Radium in stream waters causes kidney, liver and brain damage. The itai itai "disease that broke out in Japan in 1947 was caused by cadmium contamination of water (Forstner, and Wittmann, 1983; Adiuku-Brown, 1997).

Gaseous waste emitted from mineral processing plants pollute the atmosphere. In the upper atmosphere they adversely affect the ozone layer. Some of these gases (e.g. acetylene, methane and nitrogen), are inert and they can cause asphyxiation by reducing the volume of available oxygen in the lungs to dangerous level for survival. Certain elements like arsenic, antimony, tin, 
gold, lead, zinc and copper form vapours or can sublime. These elements can form part of mists released from the chimneys of mineral processing plants. These mists pollute the environment at different levels of severity. Hence, the tin smelting plant at Jos, the iron ore processing plant at Itakpe and the Steel Rolling Mills at Oshagbo, Jos and Katsina, as well as other mineral processing plants in the country can be sources of serious environmental pollution in their areas of location.

Another serious source of hazard through mining, is the incidence of mine collapse, which is seldom reported in Nigeria. On Wednesday, 29 ${ }^{\text {th }}$, October, 2003, the Voice of America (V.O.A) reported that underground flood killed about eight miners in Russia who were working at a depth of about 700 metres underground. It observed that mines accidents have been frequent in Russian mining industry since the break -up of the Union of Soviet Socialist Republic (USSR) in December 1991.

In June, 2003, BBC announced that fourteen miners died of asphyxiation in Russia when a gas ventilation system collapsed. On Saturday, $10^{\text {th }}$, April, 2004, it also reported a mine explosion at 10 am killed 28 people and trapped about 30 miners inside the mine. They also expressed surprise that mine mishaps have been a recurring phenomenon in Russia since the post-Soviet (USSR) era.

On Friday $30^{\text {th }}$, April 2004, China Radio International (CRI) reported that, at least 35 miners were buried alive in a mine when a methane gas explosion occurred in North-west China. The mine is located in the remote mountain area where communication is difficult. Efforts to rescue the 14 remaining miners trapped underground were being intensified. Still on Monday, $3^{\text {rd }}$ May 2004, the report had it that the death toll had risen to 39, and that the General Manager and the Chief Mine Engineer and two senior officials had been arrested for questioning on the incident. The report concluded that mine explosion has been rampant in China in recent years, with about 7200 accidents occurring in the past ten months.

Yet, in another incident, the BBC, on $11^{\text {th }}$ April, 2004, also reported that mud slide from a flooded underground mine killed about ten people at Peru and rendered about 800 tourists stranded and covering train tracks at Angua Kalenti area. The mud slug destroyed homes and rail lines as a result. Mine accidents appear to be an almost everyday phenomenon all over the world with their attendant consequences and more of these events might have escaped the authors recordings during radio broadcasts due to unavoidable circumstances. Although, the high frequencies of these phenomena appear surprising to be imagined, the reports were real, otherwise these reputable radio media would not have aired these events of high spatial and fatal variability for fear of contradiction or litigation.

Mortimer (1998), on the other hand, has observed that minerals are the essential ingredients that enable us to make more of life. However, as it can be seen above, the extraction, processing, delivery and use of these minerals have an adverse impact on the environment. As advanced society is placing increasing emphasis on the environmental sustainability of all human activity, the need for ameliorating mining hazards becomes increasingly pertinent as well in this regard.

\section{Strategies for Reducing Impacts of Mining Activities}

The colossal damage done to the environment by mining and mineral exploitation activities seem to have reached an alarming dimension, and is the cause of incessant conflicts (often fatal) between villagers and the mineral entrepreneurs, especially in the Niger Delta of the country. Achieving the right balance between protection of the environment and wealth creation through mineral development is one of the major issues facing the minerals industry and planning process today (Highley, and Bloodworth, 1998). Balancing the demand for minerals and the need to protect the environment is the task of the land-use planning system. They concluded, as a society, we require an adequate supply of minerals, and we also require that the environment should be well cared for. The formulation of strategies to achieve this, therefore, seems justified. 


\section{After-Use of old Mines and Quarries}

Old mines and quarries are a valuable resource and the spaces created by them in the country are seldom filled. Filling these spaces with domestic waste is a common way of restoring them to previous ground level, but not all sites are geologically suitable or near enough to the places where waste is produced to make this use economic.

Rain, for example, falling on domestic waste stimulates biodegradation, generating methane, carbon dioxide, and a highly polluting liquid known as leachate. If the geology is permeable (e.g. sand, gravel or fractured rock), this leachate may enter and pollute groundwater. Landfill gas may also migrate, causing an explosion or suffocation if it enters housing or an adit in the mine. There are many cases of ground water pollution and there have been several incidents of gas explosions in the country, which are seldom reported.

Gas or lechate, can however, be prevented from escaping by sealing the quarry with clay or very tough impermeable plastic, but leachate and gas are still produced within the site and have to be removed. However, fortunately, landfill gas can be used to generate electricity; so many operators in developed countries now control gas emissions at the same time as recovering energy. Leachate, on the other hand, usually has to be pumped out, treated and disposed of elsewhere. Williams (1998), has noted clearly that disposing of waste into quarries can create major environmental problems requiring costly engineering site preparation and ongoing management.

Abandoned quarries in Nigeria can be scenically very attractive and can enhance the countryside, producing wonderful habitats for birds, animals and plants, and producing a haven for fish and fishermen. Even if they are less attractive, quarries can still be an asset to specific groups of people. Recreational uses abound, if the geology and hydrogeology are right. They include water sports such as boating, water skiing, canoeing, rowing, sailing and scuba diving or off reading for Land Rovers vehicles, motorbikes and mountain bikes. In addition rock climbing, horse riding, shooting clubs, caravan and picnic sites, film sets, geological trails, rock festival sites, firework and bonfire sites and wilderness play grounds, etc. are all possible uses of abandoned quarries. Alternatively, industrial developments, supermarkets and car parks are often possible, and some quarries are known to be used for explosives and ballistics research (op. cit).

Also, just like quarries, underground mines or spaces purposely excavated can be put to use, especially if they are dry. Storage (oil, liquefied petroleum gas, wine, art treasures, ordnance), mushroom growing, mountain biking, industrial archaeology museums and research facilities for detection of elementary particles are all examples of diverse uses for underground space.

\section{Reducing the Effects of Minewater Pollution}

From Tables 1 and 2 (in the Appendix), it is glaring that extensive mining activities had, and/or are still going on in the country. Mining has always had to contend with underground water. Historically, the development of the steam engine enabled large volumes of water to be pumped out from mines. On abandonment, the mine workings are liable to flooding unless pumping is continued. In the early to middle twentieth century, coal and tin mining were the most extensive activities in Nigerian mineral exploitation.

Local ochrous discharges into rivers and streams from long abandoned, generally smallscale mine workings, are known from the older parts of these mineral fields. A similar situation is also experienced in other mineral mine locations in the country. Because mine (e.g. coal) workings are often complexly interlinked underground, often from one colliery to another, it is necessary to maintain a network of pumping stations to de-water abandoned mines, in order to prevent the flooding of currently operating collieries. However, because of exhaustion, or due to economic or political factors sustained de-watering of old mines would be difficult. Barriers of un-worked coal can sometimes be left as a protection against flooding from adjacent 
waterlogged old workings.

There are other strategies that can reduce the environmental hazards posed for example, by metalliferous mine waste generated by mining activities. Current mines can he planned to minimize the amounts of hazardous wastes they produce, but for historical mines, where waste already exists, some kind of remedial action may be required. Hazards from such existing wastes can be reduced by using one or more of many strategies. These strategies include removing the waste to a locality where it will constitute a lower hazard (e.g. the dumping of toxic waste at Koko, in Delta State, Nigeria by an Italian Firm some years ago), or containing it using engineered barriers such as tailings dams, reed beds, geomembranes or clay barriers.

These measures, Metcalfe et al (1998) may not be feasible where wastes arise from largescale historical mining in developing countries with scarce resources. In these circumstances, the most appropriate way to minimize the hazard may be suitable land-use planning, so as to restrict the use of the contaminated site. This approach will be most effective where the hazard will diminish naturally with time.

In practice, the resources available to minimize the hazard posed by any given mine waste are always finite. Therefore, available resources must be deployed in a manner appropriate to the size of the hazard and the risk to health that it represents. To quantify the risks, in the present and the future, he stressed it is necessary to predict the concentrations of potentially toxic elements at any point between the source (mine waste) and receptor (human populations, livestock, vegetation, etc) at any time from the present onwards. There concentrations depend upon: the physical and chemical characteristics of the solid mine wastes themselves, the hydraulic conditions with and around these wastes; and the chemical processes which reduce or concentrate toxins after they have been leached from mine workings and solid waste deposits. To predict the risk arising from these contaminants, (op. cit) we need to know their partitioning between solid and aqueous phases, the migration pathways, and the rates of migration.

It is necessary to quantify the metal pollutants' distributions between different dissolved forms (chemical speciation), and the nature and rates of reactions in which they take (including adsorption, precipitation, and dissolution reactions). The directions and rates of movement of the transporting media, most importantly water, must also be constrained. Thus, the estimation of risks from mine wastes draws upon the disciplines of hydrogeology, geochemistry, mineralogy and petrology.

\section{Discussions}

Nigeria is fortunate in being well endowed with a great variety of mineral resources, the nature and distribution of which are related to the complex geological history (Pre-Cambrian origin) of the country and its adjacent continental shelf. These resources (see appendix) are national assets and their extraction and, more importantly their use, make an essential contribution to wealth creation, the nation's infrastructure and the quality of life of its population.

However, the extraction, processing, delivery and use of these minerals have some negative impact on the environment. This is more so evident when it has been established that mining had been a very significant part of the Nigerian economy during the colonial era and can still be in this twenty-first century. Moreover, the paper fears that the creation of the Ministry for Solid Mineral Resources, to coordinate mining activities might have heightened considerably the tempo of mineral exploitation in the country; and this combined with any synergistic fusion of the exogenic and endogenic disturbance processes, may lead to some unpleasant and challenging environmental catastrophes (earthquake, tremor, volcanic eruptions, etc). This state of opinion may be sustained judging from some facts. Adiuku-Brown (1997) has observed that natural catastrophes such as earthquake and volcanic eruptions have not been experienced in Nigeria for some decades now. Nigeria by virtue of its location in West Africa is within intraplate area. Therefore, according to the simple concept of plate tectonics it is unlikely 
to experience such hazardous earth processes as experienced in countries located within the Circum-pacific and the Alphine belts.

However, volcanic cones and ashes dated back to the lower Tertiary and Quaternary geologic periods can be seen in Miango, Vom, Barkin Ladi and Panyam areas of Plateau State. These have remained inactive for several years and do not seem to constitute a problem as could be expected in other countries located in active earthquake zones.

Nevertheless, Ajakaiye et al (1989) recorded that in 1933 in 1939, earth tremors had been felt in Warri and Lagos environs respectively. Others are the $2^{\text {nd }}$ of July, 1961 earth tremor within Asaga, Ohafia near Umuahia, in which a crack of about 10 metres deep, 5m wide and $90 \mathrm{~m}$ long was reported to have been produced across the road. Earth tremors were also recorded in parts of Bauchi State in 1981, Kano in 1975, ljebu Ode in 1984, ljebu Remo in 1984 , and Yola in 1984. The incessant flooding of the Victoria Island, Lagos is also attributed to as a possible indication of the fact that Nigeria may be witnessing some earth movements beneath the ocean floor. This may have arisen from mining activities in conjunction with seismic and hydrothermal processes whose impacts are not always localized but may produce long range, endogenous multi-temporal and spatial dimensional effects outside the vicinity of operation.

In Nigeria, mining operations consist of opencast and underground mining. In opencast mines, the quarry produced for example, is often deeper than the water-table so there is a tendency for it to be flooded, and often the surface and underground water are polluted by effluents and waste materials from the mines. The mine water may be acidic or alkaline. Sometimes a part of the quarry may become unstable and collapse or cause local landslide. The tin mine at Sabon Gida Kanar exhibits this problem of local landslide.

Furthermore, most of the underground mines in Nigeria are the illegal "Lotto" mines. The shafts are narrow and are sunk manually. No obvious provision is made for ventilation; however, the person who is lowered down the shaft takes a lighted candle along. When the candle quenches it means that the oxygen in the shaft is no more sufficient. The risk of this device is that the candle uses up part of the limited supply of oxygen, and also the naked light can ignite a combustible gas in the shaft and cause an explosion. The reports of mine accidents in the country, resulting from explosions or collapse are seldom made known to the public, yet these incidents occur with high frequencies to the detriment of miners, the environment, and national economy. There is also no database on the mine locations and the contributions of our minerals to the Gross Domestic Product (GDP) of the country. For example, on Wednesday $16^{\text {th }}$ of June, 2004, the Minister for Solid Mineral Resources decried the extensive devastation of the environment in Niger State as a result of illegal mining of gemstone, sapphire and gold, as well as capital flight as a result (reported during NTA Network News at 9.00 p.m.).

\section{Conclusions and Recommendations}

Historically, mining activities have produced wastes, which contain pollutants of toxic chemicals. Such wastes often pose a significant risk to the health of living organisms. In Nigeria, Ghana, South Africa, and most developed countries, such as United Kingdom, Canada, France, etc, the hazards represented by these wastes mainly reflect historical mining activities. Furthermore, the wastes can limit the ways in which surrounding land can be used, and in extreme cases can cause major pollution incidents. Hence, rightly enough, modern society is placing increasing emphasis on the environmental sustainability of all human activity. As well, the extraction of minerals can be highly visible and is increasingly the focus of attention for many environmental pressure groups. In consequence, the danger is that the minerals industry may come to be regarded as "unacceptable" resulting in significantly reduced activity, declining economic contribution and worsening balance of payments as imports rise. This calls for sustainable mining aimed at reducing the impacts on the environment; and different methods have been discussed.

The paper therefore, suggests a holistic approach to addressing the effects of mining 
activities and the wastes generated. In doing this, studies aimed at evaluating the hazards represented by different kinds of mine waste should be embarked upon. For example, "environmental impacts of gold and complex sulphide (inclusion minerals) mining" and hazard ranking system for solid waste disposal can be initiated.

This can be achieved by conducting Monte Carlo simulations in which values of all the key parameters, such as; ground water $\mathrm{PH}$, oxidation state and concentration of chloride are chosen at random between limits suggested by the uncertainties on their measured values. Theoretical simulations of the mobility of each toxin are then undertaken for each set of parameters.

This approach builds up a set of predictions of the mobility of each toxin, and enables an estimate to be made of the probability that any toxin will be mobile. This information is then used to estimate risk using computer codes such as the United State (US) Environmental Protection Agency (USEPA) approved Risk Assistant (Metcalfe et al, 1998). The aim is to identify which parameters are particularly important for estimating risks under any given waste management scenario. This information will be used to devise a method for ranking the hazards posed by for example, a specific metalliferous mine waste, using easily acquired information such as the identities of the minerals in the wastes, the levels of local water-tables, and the local topography. Such a method will enable appropriate hazard remediation or avoidance strategies to be chosen.

This approach is novel in that it takes account of all the major interrelated chemical and physical processes and their associated uncertainties. Because the approach adopted will allow a quantitative estimate of risk to be made, it will be possible to compare risks arising from hazardous mine wastes with other environmental risks. The approach will, in turn, enable resources to be targeted at the greatest risk, in accordance with the principles of BETNEEC (Best Available Technology Not Entailing Excessive Cost).

In the past some loopholes in the Nigerian mining regulations (FRN, 1965, 1984; FMMP \& $S, 1990)$ were exploited by the mining companies, because those regulations did not make it mandatory for the mining companies to reclaim land devastated by their mining and mineral processing activities. The new laws envisaged should emphasize that, and the Federal Ministry of Environment, government, non-governmental agencies should strongly see to the implementation.

The need for the adoption of a computer interactive minerals Geographical Information System (GIS) database for mapping, visualizing and assessing mineral deposits and their impacts on the environment is also suggested. Three - Dimensional (3-D) - visualization and virtualreality modes are being used increasingly in all areas of life, from architecture to surveying and mapping; and current applications include mineral exploration and mine development.

$3 \mathrm{D}$ - modelling is also becoming extremely important in assessing the environmental impact of new developments. For example, it is possible to create a model of an open pit before it is dug, with appropriate landscaping to enable planning authorities to visualize the appearance of the site before, during and after working, from any possible angle, Norton (1998), for better mine areas restoration initiatives,

Luckily, somehow, it was announced on Monday $14^{\text {th }}$ June, 2004 during the 7.00 p.m News by the National Television Authority (NTA), Minna that the Federal Government of Nigeria has approved the establishment of a 7-year solid mineral development plan for the country to check environmental degradation. It is hoped that this would be implemented when operational since it will be a step towards the achievement of the dream of this article.

\section{References}

Adekoya, J.A., (1995). Negative environmental impact of mineral exploitation in Nigeria. Proceedings of the Regional Training Workshop on impact of human activities on the West African Savanna, held at the Federal University of Technology, Akure, Nigeria $23^{\text {rd }}-26^{\text {th }}$ July, 1995; UNESCO - MAB Sponsored.

Adiuku - Brown, M.E., (1997a). Geology related environmental issues: the situation as it affects Nigeria. Proceedings of Environmental Education for Sustainable Development: Focus on 
Nigeria; Department of Arts \& Social Science Education, University of Jos, Nigeria. Udoh, S.U, and Akpa, G.O. (Edited), 499pp.

Adiuku - Brown, M.E., (1997,b). The role of the geologist in controlling pollution and maninduced geologic hazards. Proceedings of Environmental Education for Sustainable Development. Focus on Nigeria. Department of Arts \& Social Science Education, University of Jos, Nigeria Udoh, S.U, and Akpa, G.O. (Edited), 499pp.

Adiuku-Brown, M.E., and Ogazi, A.E., (1991). Heavy metal pollution :from mining practices: A case study of Zurak. Journal of Mining and Geology; Vol. 27, No.2, pp. 205-211.

Ajakaiye, D.E., Daniyan, M.A., and Ojo, S.B-N., (1989). Detection and prediction of earthquakes. Proceedings of National Seminar on Earthquakes in Nigeria. Pp. 48-61.

Ajayi, S.D., and Adelaye, S.A., (1977). Pollution studies on Nigerian Rivers. A preliminary report on the pollution level of Rivers Ona and Ogunpa. Bulletin of the Chemical Society of Nigeria; vol. 2, pp. 77-82.

Bafor, B.E. (1979). Aspects of Nigerian Mineral Laws. Journal of Mining Geology; Vol. 16, No.1, pp. 1-5.

Federal Ministry of Mines, Power and Steel, FMMP\&S. (1990) Guidelines for mining operations in Nigeria; Lagos: Mineral Resources Department.

Federal Republic of Nigeria, FRN., (1965). Mines Manual Containing Minerals Act (Cap. 121 of 1964) and Ancillary Legislation. Federal Government Printers, Lagos.

Federal Republic of Nigeria, FRN., (1984). Decree No. 29 Minerals Act. (Amendment). Decree 1984. Official Gazette, No. 28, vol. 71, P.A. 557, Federal Government Printers, Lagos.

Forstner, D., and Wiltmann, GT.W., (1983). Metal Pollution in the Aquatic Environment ( $2^{\text {nd }}$ Edition). Berlin; Springer Velag, Publication Company, Ltd.

Geological Survey of Nigeria, GSN (1987). Mineral and industry in Nigeria. Geological Survey of Nigeria Publication, Kaduna, Nigeria.

Highley, D., and Bloodworth, A., (1998). Minerals in your backyard; Mineral resources maps from the BGS. Earthwise Magazine; British Geological Survey, Issue 12, P. 10

Honda, K. (1991). Monitoring of revegetation area in Asio devastated land - How expensive and difficult to restore the destructed forest. Asian Journal of Remote Sensing; vol. I, No. I, pp. $127-128$.

Kolesnik, W. (1978). Motivation: Understanding and influencing Human Behaviour. Cited in Eggen, P.D., and Kauchka, D., (1992) Educational Psychology, Classroom connections, New York, Macmillan Publication Company Ltd.

Metcalfe, R., Breward, N., and Klinck, B., (1998). Minimizing the impact of mine waste: Strategies to reduce the effect on the environment. Earthwise Magazine; Published by the British Geological Survey; Issue No. 12, pp. 14 - 15.

Mogbo, T.C. (1999). An integrative approach to environmental reconstruction and politics in Nigeria. Journal of Environmental Sciences, University of Jos, Nigeria; Vol. 3, No. I, pp. 1 -7.

Mortimer, J., (1998). Background and purpose of minerals' 98 Earthwise Magazine; Published by the British Geological Survey; Issue, No. 12, pp. 4 - 5.

Norton, G., (1998). 3D Modelling: Visualising and assessing complex mineral deposits. Earthwise Magazine; Published by the British Geological Survey; Issue, No. 12, p. 19.

Sharma, J.L, and Joshi, M .. D., (1985). A Text Book of Advanced Surveying. C.B.S . . Publishers \& Distributors, India; 998 pp.

Ugodulunwa, F.X.O, and Taiwo, A.O., (1997). Reduction of environmental impact of mining and mineral processing through environmental education. Proceedings of Environmental Education for Sustainable Development: Focus on Nigeria; Department of Arts \& Social Science Education; University of Jos; Udoh, S.U., and Akpa, G.O. (Edited), 499pp.

Warren, K., (1973). Mineral Resources. United Kingdom; Pengiun Book Publishers Ltd.

Williams, G. (1998). After-use of quarries: Old mines and quarries as a valuable resource. Earthwise Magazine; Published by the British Geological Survey; Issue, No. 12, p. 11. 


\section{APPENDIX}

\section{Table 1: ECONOMIC MINERALS OF NIGERIA}

\begin{tabular}{|c|c|c|}
\hline Class & Name & Location \\
\hline \multirow{12}{*}{ Motallic } & 1. Iron & $\begin{array}{l}\text { Itakpe, Agbaja, Plateau, Udi Plateau, Birnin } \\
\text { Gwari, Muro-Maru, Chokochoko, Birnin Goga, } \\
\text { Ajase. }\end{array}$ \\
\hline & 2. Manganese & Mallam Ayuba, Maru, Birnin Gwari, \\
\hline & 3. Tin & $\begin{array}{l}\text { Jos Plateau, ljero-Ekiti, Ririwai, Banke, Jemaa, } \\
\text { Godogodo, Kalato, Rishi, Pakaru, Tudun Fulani, } \\
\text { Panshanu, Ningi, Kulfana, Malamawa. }\end{array}$ \\
\hline & 4. Niobium (Columbite) & Jos Plateau, Nassarawa \\
\hline & 5. Tantalum (Tantalite) & Jos Plateau, Nassarawa \\
\hline & 6. Gold & $\begin{array}{l}\text { Ife-llesa area } \\
\text { Gwari, Maru Zamfara, Okolom, Isanlu area, } \\
\text { Birnin Yauri }\end{array}$ \\
\hline & 7. Silver & Ishiagu, Ameka, Ameri \\
\hline & 8. Lead & $\begin{array}{l}\text { Ishiagu, Enyigba, Ameri Ameka, Arufu, Akwana, } \\
\text { Zurak, Gombe }\end{array}$ \\
\hline & 9. Zinc & $\begin{array}{l}\text { Ishiagu, Enyigba, Ameri Ameka, Arufu, Akwana, } \\
\text { Ririwai }\end{array}$ \\
\hline & 10. Chromium & Sado area \\
\hline & 11. Tungsten & Jos Plateau, Egbe \\
\hline & 12. Molybdenum & Kigom Hills \\
\hline \multirow{21}{*}{ Non-metallic } & 13. Limestone & $\begin{array}{l}\text { Nkalagu, Ewekoro, Sagamu, Ibeshe, Nfamosing, } \\
\text { Yandev, Igumale, Odomake, Ashaka, Kalambaina, } \\
\text { Okoluse / Arimogija }\end{array}$ \\
\hline & 14. Marble & $\begin{array}{l}\text { Ukpilla, Igarra, Ososo, Burum, Kwakuti, Igbetti, } \\
\text { Jakura }\end{array}$ \\
\hline & 15. Feldspar & Egbe, Okene arwa, Gwaza, Iwo, Ijero-Ekiti \\
\hline & 16. Gypsum & Kalambaina, Sabongida, Ora area, Idogo area \\
\hline & 17. Barytes & Azara, Arufu, Akwana \\
\hline & 18. Clay & All states of the Federation \\
\hline & 19. Glass Sand & Igbokoda, Badagry, River Chalawa, Ughelli \\
\hline & 20. Diatomite & Bularaba \\
\hline & 21. Quartzite & Esa Oka, ljero,-Ekiti, Okemesi \\
\hline & 22. Sillimanite & Olode area, near Ibadan \\
\hline & 23. Kyanite & Sabon Birnin Gwari \\
\hline & 24. Mica & ljero Ekiti, Iwo area \\
\hline & 25. Piezoeloctnc quartz & Pankshin, Biu, ljero Ekiti \\
\hline & 26. Phosphate & Ife, Oshosun, Idogo, Sokoto \\
\hline & 27. Talc & Apomu, Ilesha, Isanlu \\
\hline & 28. Asbestos & Shemi \\
\hline & 29. Trona & Gashua, Nguru, Zumo \\
\hline & 30. Salt springs & Awe, Akwana, Okposi, Uburu, Ikom \\
\hline & 31. Flounte & Awe, Akwana, Arufu \\
\hline & 32. Beryl (aquamarine) & $\begin{array}{l}\text { Jos Plateau, Lokaja-Kabba Junction, Isanlu area, } \\
\text { Ijero, Ekiti-Olode, Iwo areas }\end{array}$ \\
\hline & $\begin{array}{l}\text { 23. Tourmaline } \\
\text { - Emeralite } \\
\text { - Rubellite }\end{array}$ & ljero-Ekiti \\
\hline
\end{tabular}




\begin{tabular}{|l|l|l|}
\hline & \multicolumn{1}{|c|}{ Schorlite } & \\
\hline & 34. Ruby & Jos Plateau, Keffi, Akwanga-Wamba area, \\
\hline & 35. Sapphire & $\begin{array}{l}\text { Jos Plateau, Akwanga area, Keffi, Jemaa, Biu, } \\
\text { Tafawa Balewa. } \\
\text { Zaria, Jos Plateau. }\end{array}$ \\
\hline & 36. Amethyst & Panbegua - Jos road \\
\hline & 37. Rose quartz & Jos Plateau \\
\hline & 38. Topaz & Gombe area, Lokaja area \\
\hline & 40. Thanium & Odoegi (Rayfield granite) \\
\hline & 41. Monazite & Jos Plateau, Nassarawa \\
\hline & 42. Xenotime & Rayfield, Bukuru and Jos Plateau in general \\
\hline & 43. Pyrochlore & Ririwai, Kigom Hills \\
\hline & 44. Coal & $\begin{array}{l}\text { Enugu, Ezima, Owukpa, Okaba, Ogboyoga, } \\
\text { Odokpono, Lafia-Obi area }\end{array}$ \\
\hline & 45. Lignite & Obomkpa, Ogwashi-Asaba \\
\hline & 46 Bitumen & Agbabu, Ofosu \\
\hline 47 Nil and Gas & Niger delta and Offshore \\
\hline
\end{tabular}

Source: Adekoya (1995)

Table 2: MINERALS CURRENTLY BEING EXPLOITED IN NIGERIA

\begin{tabular}{|c|c|c|c|}
\hline S/No & Mineral Name & Locality & Current Level of Exploitation \\
\hline 1 & Iron & Itakpe & $\mathrm{L}$ \\
\hline 2 & Tin & Jos Plateau Nassarawa & $M, S \quad M$ \\
\hline 3 & Niobium & Jos Plateau & Won-as-by-product of tin mining \\
\hline 4 & Monazite & Jos Plateau & - ditto - \\
\hline 5 & Xenotime & Jos Platteau & - ditto - \\
\hline 6 & Gold & Itagunmodi & $\mathrm{S}$ \\
\hline 7 & Lead & $\begin{array}{l}\text { Ishiagu } \\
\text { Enyigba } \\
\text { Ameka, Ameri }\end{array}$ & $\begin{array}{l}M \\
M \\
M\end{array}$ \\
\hline 8 & Silver & $\begin{array}{l}\text { Ishiagu } \\
\text { Ameka, } \\
\text { Ameri }\end{array}$ & Won-as-by-product of tin mining \\
\hline 9 & Znic & $\begin{array}{l}\text { Ishiagu } \\
\text { Enyigba } \\
\text { Ameka, Ameri }\end{array}$ & Won-as-by-product of tin mining \\
\hline 10 & Limestone & $\begin{array}{l}\text { Ashaka } \\
\text { Ewekoro } \\
\text { Nfamosing } \\
\text { Nkalagu } \\
\text { Kalambaina }\end{array}$ & $\begin{array}{l}L \\
L \\
L \\
L \\
L\end{array}$ \\
\hline 11 & Marble & $\begin{array}{l}\text { Burum } \\
\text { Igbetti } \\
\text { Igarra } \\
\text { Jakura } \\
\text { Kwakuri } \\
\text { Ukpilla }\end{array}$ & $\begin{array}{l}M \\
M \text { (presently dormant) } \\
M \\
L \\
L \\
L\end{array}$ \\
\hline 12 & Feldspar & Gwoza & M \\
\hline 13 & Gypsum & Wurno & $\mathrm{S}$ \\
\hline 14 & Barytes & Azara & $\mathrm{S}$ \\
\hline 15 & Clay & Omi Adio & $\mathrm{L}$ \\
\hline
\end{tabular}




\begin{tabular}{|l|l|l|l|}
\hline & & Ozubulu & L \\
& & Nraguta & L \\
& & Kano & L \\
& & Lkorodu & L \\
& & Ire & L \\
\hline 16 & Glass sand & Badagry & L \\
& & Igbokoda & L \\
& & Ughelli & L \\
\hline 17 & Construction sand & All parts of the Federation & L \\
\hline 18 & Construction stones & All parts of the Federation & L, M, S \\
\hline 19 & Laterite & - ditto - & - ditto - \\
\hline 20 & Beryl & ljero-Ekiti & S (mainly illegal mining) \\
& & Jos Plateau & S - ditto - \\
& & Olode & S - ditto - \\
\hline 21 & Tourmaline & ljero-Ekiti & S (mainly illegal mining) \\
\hline 22 & Sapphire & Jos Plateau & S - ditto - \\
& & Akwanga area & S - ditto - \\
\hline 23 & Ruby & - ditto - & S - ditto - \\
\hline 24 & Topaz & Jos Plateau & S - ditto - \\
\hline 25 & Coal & Enugu & L \\
\hline 26 & Oil and Gas & Niger Delta & L, M \\
\hline & & & \\
\hline
\end{tabular}

Source: Adekoya (1995)

$\mathrm{L} \quad=$ large scale exploitation

$M=$ medium scale exploitation

$\mathrm{S}=$ small scale exploitation 